\author{
Imanaly Akbar $^{1,2^{*}}$, Z.K. Myrzaliyeva ${ }^{3}$, A.Z. Tazhekova ${ }^{4}$, B. Kenesbekkyzy ${ }^{5}$ \\ ${ }^{I}$ State Key Laboratory of Desert and Oasis Ecology, Xinjiang Institute of Ecology and Geography, \\ Chinese Academy of Sciences, Urumqi, China; \\ ${ }^{2}$ University of the Chinese Academy of Sciences, Beijing, China; \\ ${ }^{3}$ Department of Modern History of Kazakhstan and Geography, SILK WAY International University, Shymkent, Kazakhstan \\ ${ }^{4}$ Department of Geography, South Kazakhstan State Pedagogical University, Shymkent, Kazakhstan; \\ ${ }^{5}$ School № 37 named after Zhansugurov, Zhanalyk village, Talgar district, Almaty province, Kazakhstan \\ *Corresponding author:yimanaili_akebaier@yahoo.com
}

\title{
Development status of the tourism products in Jabagly village near the Aksu-Jabagly world heritage site
}

\begin{abstract}
Tourism is one of the main sources of income in many countries; even some states depend highly on the tourism industry at present. The main purpose of tourism business activities is to create competitive tourist products in the international market. Achievement of these aims requires the development of the governmental regulation system, support of the tourism industry, the usage of promotion methods of tourism products. The article presents and assesses the state of development of the most necessary tourism products for the development of the tourism industry on the example of Aksa-Jabagly Nature Reserve in Kazakhstan. The results of the study show that if we consider the development level of the four most important tourist products, such as accommodation, transportation, tourist attractions and electronic service, then we can say that the level of their development and the conditions for providing quality services to tourists are relatively good according to the three previous indicators. Based on the analysis of the quality of electronic services in the field of research (the main criteria: telephone signal, Internet speed, electronic tickets, etc.), we found that the level of eservice development in this region is low, despite the fact that Kazakhstan has the potential of using highquality internet coverage in its current development status.
\end{abstract}

Keywords: development status, tourism products, tourists, Jabagly village, Aksu-Jabagly, nature reserve, world heritage, Kazakhstan.

\section{Introduction}

With the rapid development of economy and society, GDP has increased year by year, people's concern about leisure activities is increasing, and the tourism industry has been developing vigorously. In many countries, tourism is a major industry that deserves our attention, and it has clearly become a global socioeconomic phenomenon [1]. It is necessary to conduct regional monitoring of the domestic tourism industry in order to identify problems in a timely manner and allocate solutions that will accelerate their development [2]. The development of rural tourism in the Republic of Kazakhstan is one of the crucial issues, because today Kazakhstan's tourism industry has been recognized as one of the important sectors of the state's economy [3]. One of the main tasks of tourism is to serve travelers, and its success depends on the positive interrelationship between all sectors. It is hoped that this synergy between travel service providers will bring a positive experience to individual tourists [4].Tourism's important role in economy and socio- cultural aspects is well accepted. But the tourism nowadays is not simple one; like going to holiday to enjoy good weather. Modern tourists have diverse interests than traditional ones. On the other hand, environmental, political and local participation issues are being raised in tourism. Hence, it is necessary to know the main products or elements of tourism industry in order to grasp the essence of the phenomena. Basically, the tourism industry includes four main products: (i) accommodation, (ii) transportation, (iii) attractions, and (iv) electronic services [5].

If tourists cannot get from one destination to another quickly and efficiently, then transportation development will make it possible. The transportation provided for tourists can be divided into air, water and land. Good transport is one of the major segments of tourism industry and the lack or insufficiency of transportation will certainly obstruct the smooth tourism development [6]. The accommodation sector includes various forms of reception facilities, which can be conveniently classified as services (including catering) or selfservice facilities. The hotel is the most important and widely recognized service provider for tourists and business travelers overnight. They may also constitute one of the key elements of a holiday package [4]. A tourist attraction is a place of interest where tourists visit, typically for its inherent or an exhibited natural 
or cultural value, historical significance, natural or built beauty, offering leisure and amusement. With our experience in the development of tourist attractions, we have changed the attractions in a visionary way, transformed the brand into a place, and made the local story vivid, tangible and memorable [7]. Electronic services have been developed in various ways to support tourism in different cities, regions and countries. They are experiencing strong growth and can meet the needs of various stakeholders, such as the urban planning policy department and the municipal tourism bureau. The continued rise of electronic services as a travel and tourism communication tool has posed challenges to destination marketing and tourism companies in the city. Electronic services form very efficient and cost-effective tools to promote new destinations [8].

The aim of this study is to examine the Jabagly village's tourism products' development level and Aksu-Jabagly nature reserve's ecological protection status in order to support the development of sustainable tourism in the western Tian-Shan natural World Heritage Sites. Through an increased understanding of tourism development opportunities, this study hopes to encourage the development of tourism in the buffer zone of the heritage sites. In this way, we can protect the integrity of the heritage site, bring income-generating opportunities to local communities near the World Heritage Sites, and offer financial support for the conservation of the sites. To help achieve these purposes, the study has two major objectives:

- Provide an up-to-date analysis of tourism products' development in Jabagly village adjacent to AksuJabagly World Heritage Site.

- To evaluate the development status of tourism products necessary for developing the tourism industry in the buffer zones of the reserve.

Study Area Overview: Jabagly village is an administrative unit of Tulkibas district. It includes the settlement of Jabagly, Abaiyl, and Russian Railway 115. The total population of the Jabagly village is 3048 people, including 2401 people of Jabagly settlement, 545 people of Abaiyl settlement, and 102 people of settlement Russian Railway 115. The center of the village is Jabagly settlement. And Jabagly settlement is $17 \mathrm{~km}$ southeast to the Turar Ryskulov town (former Vannovka), the administrative center of Tulkibas district. Jabagly settlement has a public transport connection with Turar Ryskulov town and Shymkent city (passport of Jabagly village, 2019). Lying adjacent to the West Tien Shan Mountains, Jabagly settlement is the gateway to Aksu-Jabagly State Natural Reserve (Fig. 1).

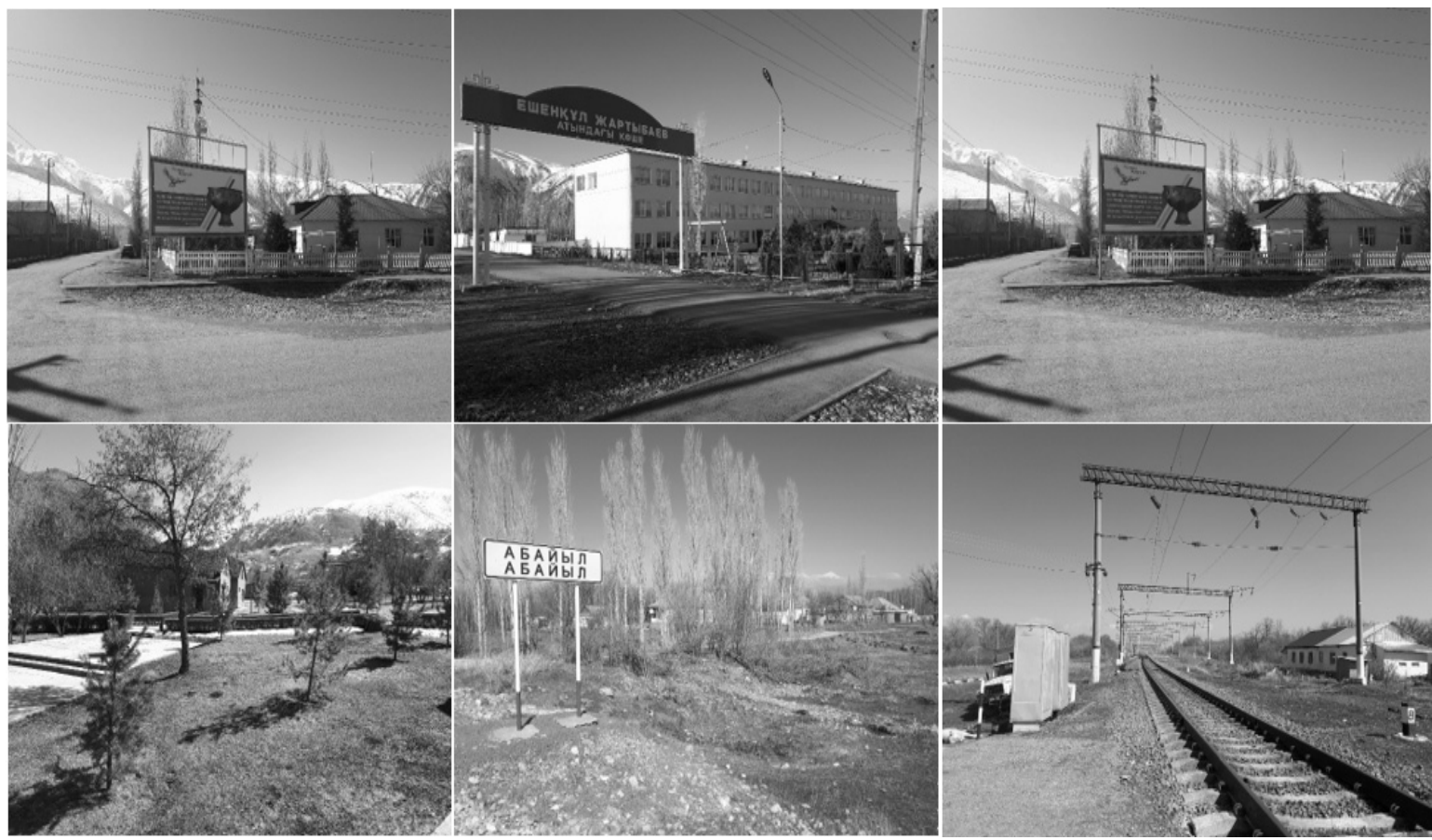

Figure 1. Infrastructure of selected research areas of Turkistan province. (C) The first author

Most people from Jabagly village center are herders and farmers, population size is larger compared with two other settlements, with a total of 2401 people, among them economically active population is 1571 people; nearly all of them are Kazakh people. There are 4 Shops, 14 limited liability companies and 4 industrial complexes in the village center. Jabagly village center has 4612.7 ha of agricultural land, 1755 ha of 
non-irrigation land, 569 ha of irrigation land, 116.7 ha of meadowland and 2172 ha of pastureland. There are 1171 cows, 645 horses, 4151 sheep and goats, and 5757 poultries in the Jabagly village center. And it owns 226 cars (Tab. 1). There are mainly 4 tour operators' offices and guest houses in the village center, two of them are located on the gateway of the Aksu-Jabagly world heritage site.

T a b l e 1

General statistics of Jabagly village. Source: passport of Jabagly village, 2019

\begin{tabular}{|l|c|c|c|c|}
\hline \multirow{2}{*}{\multicolumn{1}{|c|}{ Elements }} & \multicolumn{2}{|c|}{ The names of settlements in the village } & Total \\
\cline { 2 - 4 } & $\begin{array}{c}\text { Settlement } \\
\text { Jabagly }\end{array}$ & Settlement Abaiyl & Russian Railways 115 & 483 \\
\hline Number of families & 395 & 71 & 17 & 3048 \\
Population & 2401 & 545 & 102 & 1921 \\
Economically active population & 1571 & 275 & 33 & 2961 \\
Kazakh & 2324 & 535 & 102 & 47 \\
Russian & 37 & 10 & 0 & 40 \\
Other ethnics & 40 & 0 & 0 & 14 \\
\hline limited liability companies & 14 & 0 & 0 & 4 \\
industrial complex & 4 & 0 & 6 & 283 \\
Number of cars & 226 & 51 & 0 & 4 \\
Shops & 4 & 0 & 95 & 4780.7 \\
\hline agricultural land (ha) & 4612.7 & 73 & 75 & 1875 \\
non-irrigation land (ha) & 1755 & 45 & 20 & 617 \\
irrigation land (ha) & 569 & 28 & 0 & 116.7 \\
the meadow land (ha) & 116.7 & 0 & 0 & 2172 \\
pastureland (ha) & 2172 & 0 & 52 & 1489 \\
\hline cows & 1171 & 266 & 47 & 738 \\
horses & 645 & 46 & 250 & 4955 \\
sheep and goats & 4151 & 554 & 250 & 7129 \\
poultries & 5757 & 1122 & & 0 \\
\hline
\end{tabular}

Settlements Abaiyl and Russian Railway 115 are located between Jabagly village center and Akbiik village of Tulkibas district. Most people from these settlements have a stable job, railway workers, population size is not large, with a total of 647 people, among them economically active population is 308 people, nearly all of them are Kazakh people. There are no Shops, limited liability companies and industrial complex in these settlements. These two settlements totally have 168 ha of agricultural land, 120 ha of non-irrigation land and 48 ha of irrigation land. The two settlements own totally 318 cows, 93 horses, 804 sheep and goats, and 1377 poultries. And they have totally 57 cars (Table 1).

\section{Materials and methodology}

This study conducted in March 2019 and comprised two main components to address the aim and objectives. For gathering relevant information about the selected research area, interviews of key experts were carried out and additional documents analyzed. The main component of the study was a desktop analysis of key documents prepared by official site of Aksu-Jabagly state nature reserve (www.aksu-jabagly.kz), official sites of relevant organizations. At the same time, we search some documents included all the general reports, mission reports and periodic reports produced in recent years as well as some documents dating further back. News and articles related to the theme of «tourism product development» (using Google Browser) were also collected and incorporated into the research.

\section{Results and discussion}

\section{Tourism industry key products' development status in Jabagly village}

The tourism industry as a whole survives because of various tourism products and services. Tourism industry is flexible. The products of tourism cannot be easily standardized as they are created for the customers of varied interests and demands. There are several tourism products and services created primarily for the tourists and also for the locals. In our research, we will discuss the development level of Jabagly village's following five major tourism industry products. 
Accommodation or guesthouses in Jabagly village

Aksu-Jabagyly State Nature Reserve is an all-season recreation place enjoying long history and being a great attraction point for lots of travelers. This unique area of South-Kazakhstan region offers a vacation adventure you will not forget. There are several tour operators which are located near the Aksu-Jabagyly Natural World Heritage site and they offer accommodations for tourists. The main tour operators and guesthouses near Aksu-Jabagyly State Nature Reserve are as follows (Table 2).

The guesthouses in Jabagly village

\begin{tabular}{|l|l|}
\hline \multicolumn{1}{|c|}{ The guest houses } & \multicolumn{1}{c|}{ The characteristics of the guesthouses } \\
\hline $\begin{array}{l}\text { Holiday villages or «Aksu- } \\
\text { Jabagly» recreation camp }\end{array}$ & $\begin{array}{l}\text { The tourist camp «Holiday villages « consisted of hotel complex including five cottages for } \\
\text { fice, sports center, car parking, etc. (www.aksubaza.kz) }\end{array}$ \\
\hline $\begin{array}{l}\text { Family tourism company } \\
\text { «Ruslan» (Figure 2.) }\end{array}$ & $\begin{array}{l}\text { «Ruslan» is a family operated tourism company specialized in the Aksu-Jabagly nature } \\
\text { reserve. Operating from the village of Jabagly and located just a few kilometers from the } \\
\text { nature reserve. Apart from organizing tours, it has its own guest house and offers accom- } \\
\text { modations for tourists (www.Jabagly.com) }\end{array}$ \\
\hline $\begin{array}{l}\text { Zhenja and Lyuda's Board- } \\
\text { ing House }\end{array}$ & $\begin{array}{l}\text { This cozy guesthouse is a small hotel on Jabagly's main street, which has rooms with two } \\
\text { comfy single beds and a private bathroom. Vegetarian meals can be arranged. Featured a } \\
\text { garden and both free WiFi and private parking are accessible at this property. It has a pri- } \\
\text { vate bathroom, some accommodations at the guesthouse also offer a balcony and a terrace } \\
\text { (www.aksu-inn.com) }\end{array}$ \\
\hline $\begin{array}{l}\text { Guesthouse of Aksu- } \\
\text { Jabagly State Nature Re- } \\
\text { serve }\end{array}$ & $\begin{array}{l}\text { This boarding house and administration office of Aksu-Jabagly nature reserve is located at } \\
\text { the same place. The guesthouse offers comfortable rooms, each room has a toilet, shower } \\
\text { with hot water per 24 hours. Guests can plan their trips in a waiting room and have their } \\
\text { meals in a dining room (www.aksu-jabagly.kz) }\end{array}$ \\
\hline
\end{tabular}

As far as two main tourism products of Jabagly village, such as accommodation and tour operators, are concerned, we can easily conclude from above table that there are enough accommodations for tourists in Jabagly village, and they are well equipped. The various services they provide are relatively complete, and the quality of accommodation meets the basic standards of rural tourism development (Fig. 2).

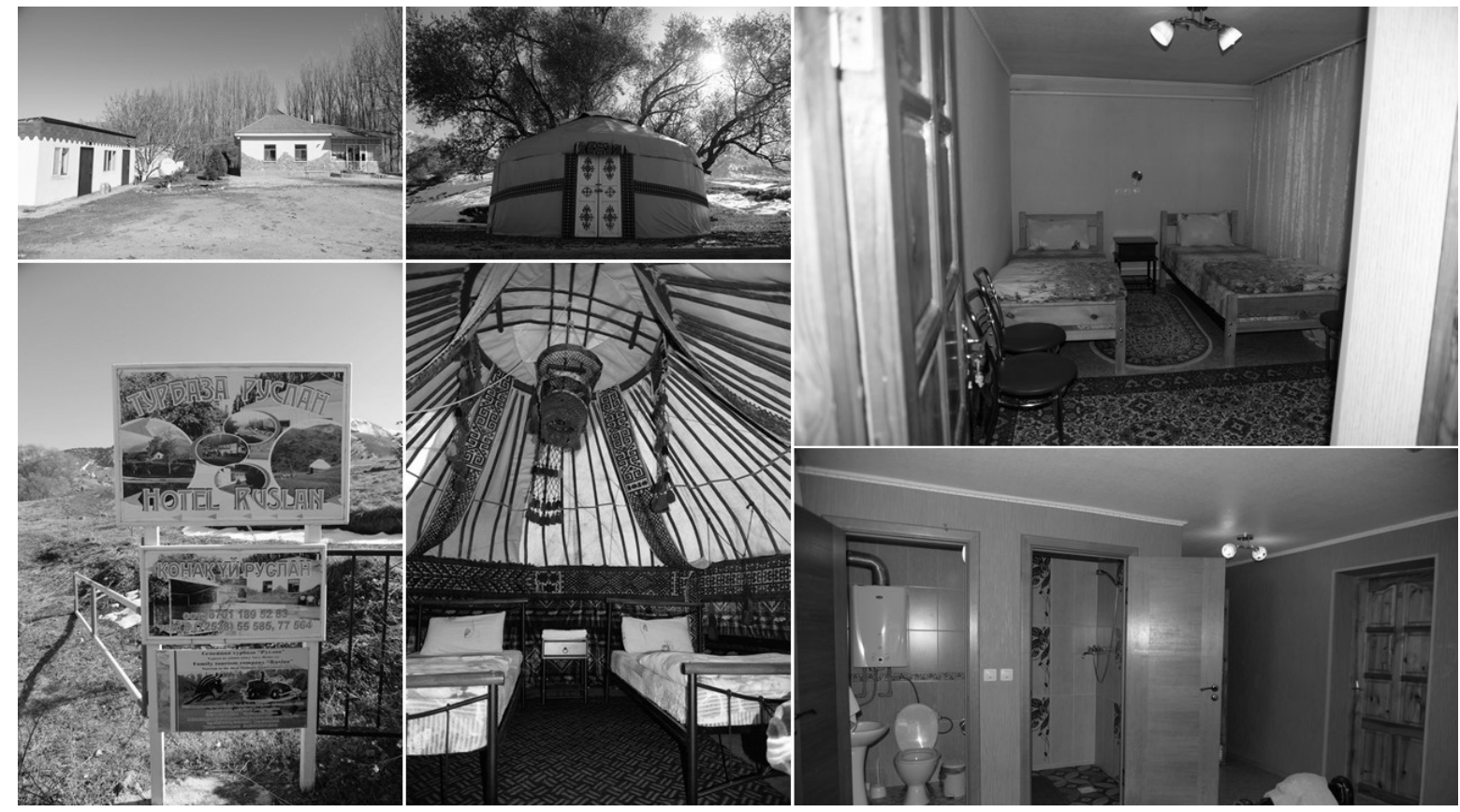

Figure 2. An accommodation in Jabagly village (guest houses of «Ruslan»). (C) The first author 


\section{Transportation development degree}

The development of the tourism industry is closely related to the construction of transportation infrastructure. Generally speaking, tourists choose different forms of tourism traffic according to local conditions for different travel needs, such as road, railway, aviation, and water, etc. When we interviewed the Akim (mayor of village), he said the transportation infrastructure of this tourist destination is well developed compared with other nature tourism attractions' in Kazakhstan. He also added that one of the accessibility advantages of the nature reserve is its geographical location, located in the middle of the two old cultural cities (Shymkent and Taraz) of Kazakhstan, only approximate $100 \mathrm{~km}$ distance from them respectively. And during our investigation period we saw the trains from two republic cities (Nur-Sultan and Almaty) of Kazakhstan to the second megalopolis (Shymkent) pass near the world heritage site, the train station is about $20 \mathrm{~km}$ route from the Aksu-Jabagly nature reserve. At the same time, the quality of car routes to the nature reserve is very good. For example, The WE-WC Highway that meets international quality standards passes through the vicinity of the nature reserve.

Almaty can rightly claim a more developed tourism industry but Aksu-Jabagly can provide a glimpse into what Kazakhstan has to offer away from there. You can get there from many directions by various transport (Table 3), and Shymkent is the best port of entry by plane.

\section{The most convenient transportation to Aksu-Jabagly heritage site}

\begin{tabular}{|l|l|}
\hline Transport types & \multicolumn{1}{|c|}{ Description of the available roads to Aksu-Jabagly natural world heritage site } \\
\hline By private car & $\begin{array}{l}\text { You can arrive at this nature reserve from Shymkent (about 100km), Taraz (about 100km), Tashkent } \\
\text { (about 220km), Turkistan (about 250km) and Almaty (about } 600 \mathrm{~km} \text { ) by private car or self-driving. } \\
\text { Jabagly village next to this natural heritage site is situated } 10 \mathrm{~km} \text { far from Tashkent-Almaty high } \\
\text { route or WE-WC Highway. }\end{array}$ \\
\hline By bus & $\begin{array}{l}\text { You take a minibus in Shymkent, there is a daily minibus from Shymkent to the village of Jabagly } \\
\text { village. Another option is to take a minibus between Shymkent and Taraz, then get off in the village } \\
\text { of Akbiik with the sign «Jabagly». From here you can take a private car to the village of Jabagly. }\end{array}$ \\
\hline By train & $\begin{array}{l}\text { The trains, from Almaty (12 hours) or Nur-Sultan (24 hours) to Shymkent, passes through the vicinity } \\
\text { of the heritage site. Buy a train ticket to Shymkent City Station. Get off at Tulkibas Railway Station. } \\
\text { The distance from Tulkibas Railway Station to Jabagly Village is } 18 \text { kilometers. Taxi there is always } \\
\text { available. Sometimes the private car of the travel agency picks you up. }\end{array}$ \\
\hline By plane & $\begin{array}{l}\text { There are flights from Nur-Sultan to Shymkent (1h 25min) and to Taraz (1h 40min) or you can fly } \\
\text { from Almaty to Shymkent (about 1 hour), then go to Aksu-Jaagly by car or bus. }\end{array}$ \\
\hline
\end{tabular}

\section{The main popular tourist attractions}

The Aksu-Jabagly Nature Reserve, though relatively small in area, is rich in wildlife and listed in the UNESCO world heritage site. Aksu-Jabagly natural world heritage site is home to multitude of landscapes and extremely diverse flora and fauna. Moreover, the mountains are also the place of origin for many cultivated fruit crops along with numerous kinds of forests and plant communities unique to that area. The unique world of animals, birds, and plants, virgin nature, as well as fascinating horseback riding and car routes attract tourists from many countries. The main popular tourist attractions in the territory of the AksuJabagyly State Nature Reserve are as follows (Fig. 3.):

Gorge Kshi-Kayndy and Pass Kshi-Kaindy: Gorge Kshi-Kayndy and Pass Kshi-Kaindyare located in Jetimsay valley at the Jabagly part of the Aksu-Jabagly state nature reserve. The way to the gorge KshiKayndy beginsfrom the left bank of the $12 \mathrm{~km}$ long Jabagly River. Thisarea is covered with a juniper and shrub forests. In spring, mountain goats and argali can be seen on the southern slope of the Gorge, and vultures and eagles often fly around. On the way, you can also see Greig and Kaufman tulips and other rare and endemic plants. In good weather, you can have a spectacular view of the central part of the reserve and its picturesque Bugulutor Peak. An alpine meadow is the best place where you can see the bear [9].

Gorge Ulken Kaindy and Pass Ulken Kaindy: Ulken Kaindy steppe is a scientific research base, including Baidaksay, the Kyzolgen lake, the Kaskabulak and the Kazanshunkyr. You can explore this tourist attraction by car, however, after passing the river Ulken Kaindy, there are roads only for horses or hiking. Coneshaped peaks, green hills and picturesque slopes can be seen in Baidaksay valley. The higher the tour road is, the fewer plants and junipers can be seen. You can enjoy the beautiful view of the mountain lake 
Kyzolgenkol and visit the petroglyphs in Boydaksay and Peak Kaskabulak on this journey. At an altitude above 3,000 m, visitors can watch argali, ibex, Himalayan snow cock, Tian-Shan brown bears and mountain goats etc. [9].

Canyon Aksu and Aksu river: Aksu Canyon is a $15 \mathrm{~km}$ long and 500m deep canyon in Kazakhstan. The Aksu Canyon harbors some forest fragments with Malus sieversii und the Turkestan Maple (Acer turkestanicum). The Aksu river formed Aksu Canyon which is $500 \mathrm{~m}$ deep, and can only be crossed in the southern part of the reserve by walking over a narrow pedestrian bridge. On a steep rock slope with southern exposure, you can observe a colony of rock swallows. There is also the possibility of meeting all of the endemic plants, rare wild animals, and birds of the reserve [9].

Gorge lakes Koksay: In the territory of the nature reserve, there are about 20 small lakes and there are few greater lakes, which is characteristic for all Western Tian-Shan. There are only small reservoirs in this reserve and some of them are only 10 square meters. They are formed near the glaciers, where the rivers collapse and have some landslides. Two major biggest lakes at the nature reserve are Kokurium, 2506 meters above sea level, and circuit of lakes Koksay, from 2620 up to 2700 meters above sea level. During the tour to the gorge Koksai river, tourists can see Koksay lakes and the waterfall in Taldysay tributary. Along the river is one of the best places in the reserve to observe the blue bird. In this area, you can see the golden eagle, lammergeyer (bearded vulture) and other birds of prey [9].
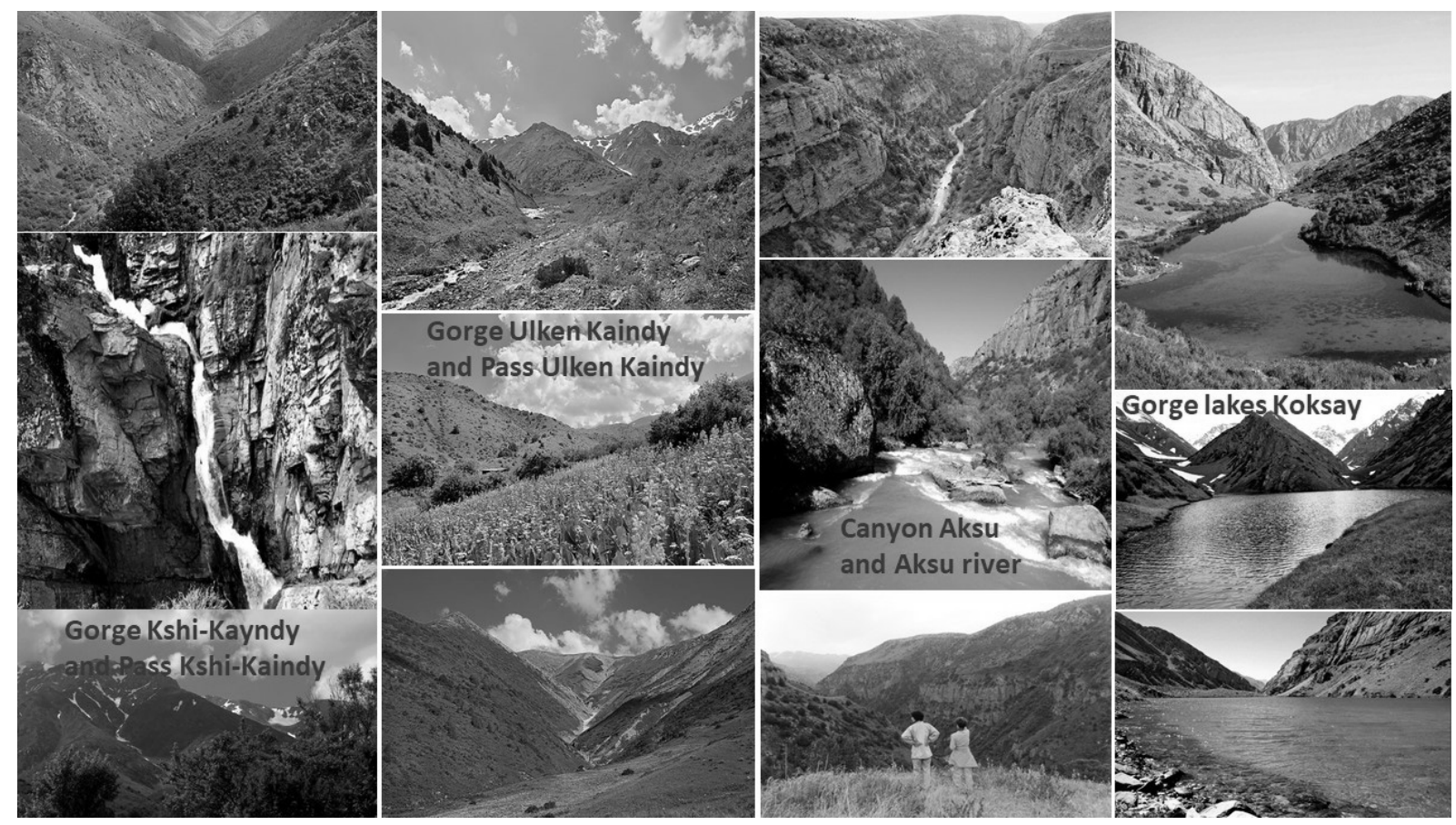

Figure 3. The most popular tourist attractions in Aksu-Jabagly reserve. (C) www.aksu-jabagly.kz

In the analysis and decision-making process of public management, urban planning and tourism, the attractiveness of destinations is crucial. The natural and cultural-historical object is characterized by both its intrinsic value, because of being researched and various forms of protection and external value, which is applied in tourism [10]. Judging from the natural beauty of the Aksu-Jabagly Nature Reserve, from the above description of the main tourist roads and the photographs taken, it can be concluded that there are many fascinating tourist attractions in the reserve that can make this place a competitive tourist destination in Kazakhstan and even in the world.

\section{Electronic services degree}

On 9th of September, 2016 at the site of the National Chamber of Entrepreneurs of Kazakhstan «Atameken» were held public hearings on the transfer of the function of MID RK on «Dissemination of information about Kazakhstan and its tourism opportunities in the international tourist market. In her speech, the Board Member, Deputy Chairman Yulia Yakupbaeva noted that of all state functions in the sphere of tourism the readiest for transmission - is the function of promotion of information about Kazakhstan at the international tourist market, and within the state [11]. Unfortunately, Kazakhstan holds 111 place among 
141 countries in the world ranking of competitiveness in the sector of travel and tourism in 2016 in terms of effectiveness of marketing activities for attraction of tourists [12]. So far, policies regarding brand destinations have been defined, and the state's official tourism portal www.kazakhstan.travel was designed in 2014. However, Kazakhstan has no travel brands (logos, slogans), and the country does not have an internationally renowned official brand travel portal. Searching for travel information about Kazakhstan on Google browser, you can find some national travel websites, such as www.visitkazakhstan.kz. However, it should be noted here that most of the state's funds are allocated to the development of the website, and very little is allocated to the promotion of the website [13]. Therefore, the Kazakhstan government still needs to promote the development of Kazakhstan's tourism digitalization.

Nowadays, the consumer demand for tourists is more obvious and presents a trend of individualization and diversification. Tourism companies also need to provide more and more one-stop integrated tourism products. All of these must have a strong information consulting service platform and an information transmission network to support them [14]. When we went to the selected research area, we interviewed the representative of the Tourism and External Affairs Office in Turkistan province. He provided us with information about the digitalization of scenic spots, Aksu-Jabagly World Natural Heritage Site. He said «the accurate information service of this tourist destination (traditional paper maps cannot provide it) is basically good, and nearly all information about tourism development is available on national and international sites, for example, you can contact a travel agency to book accommodation and travel routes near the nature reserve you need in advance, or book them online at any time.». However, when investigating this tourist destination, we found that most of the electronic services in the scenic area could not meet the global standards of online service standards. Although you can use your various electronic contact tools and Internet service at the Aksu-Jabagly tourist destination, their signal is bad and the speed of the internet is relatively slow ( 2 or $3 G)$. And the tourism department of this nature reserve office doesn't use automatic ticket selling and checking, Global Position System, sensor networks, and environment monitoring systems at all, which are the most significant elements to improve its core competitiveness and increase consumer satisfaction. Through the above-mentioned different types of travel service systems, the tourists in the destination can be informed of the traffic, weather information, passenger distribution and other real-time information in the scenic spots during the tour.

\section{Conclusion}

As defined by UNWTO, a Tourism Product is «a combination of tangible and intangible elements, such as natural, cultural and man-made resources, attractions, facilities, services and activities around a specific center of interest which represents the core of the destination marketing mix and creates an overall visitor experience including emotional aspects for the potential customers. A tourism product is priced and sold through distribution channels and it has a life-cycle» [15]. The level of development of tourism products is a clear manifestation of the development of the tourism industry in one region. There are many types of tourism products, more than a dozen, and in our research article, we have identified the development of four major tourism products in the Aksu-Jabagly Nature Reserve, with some concrete examples. If we evaluate the development level of the four types of tourism products, we can give a good assessment of three of them: accommodation, transport and tourist attractions. And one of them (e-services for tourism) is the low level of development. Electronic service in this area needs to be improved with the support of relevant organizations, as in the 21st century, e-services are one of the most important tourism products in the development of tourism systematically.

\section{References}

1 Cracolici M.F. The attractiveness and competitiveness of tourist destinations: A study of Southern Italian regions / M.F. Cracolici, P. Nijkamp // Tourism management. - 2009. - Vol. 30, Iss. 3. - P. 336-344. https://doi:10.1016/ j.tourman.2008.07.006

2 Aliyeva S. The Socioeconomic Impact of Tourism in East Kazakhstan Region: Assessment Approach / S. Aliyeva, X. Chen, D. Yang, K. Samarkhanov, O. Mazbayev, A. Sekenuly, A. et al. // Sustainability. — 2019. — Vol. 11, Iss. 17. — P. 4805. https://doi:10.3390/su11174805

3 Tleubayeva A. Rural tourism as one of the priority factors for sustainable development of rural territories in Kazakhstan / A. Tleubayeva // Journal of Environmental Management and Tourism (JEMT). — 2018. — Vol. 9, Iss. 06(30). — P. 1312-1326. http://dx.doi.org/10.14505/jemt.v9.6(30).21

4 Camilleri M.A. Tourism planning and destination marketing / M.A. Camilleri // Emerald Publishing Bingley. - 2019. https://doi.org/10.1108/978-1-78756-291-220181014 
5 Yasarata M. Politics and sustainable tourism development - Can they co-exist? Voices from North Cyprus / M. Yasarata, L. Altinay, P. Burns, F. Okumus // Tourism Management. - 2010. - Vol. 31, Iss. 3. - P. 345-356. https://doi:10.1016/ j.tourman.2009.03.016

6 Dileep M.R. Tourism, Transport and Travel Management / M.R. Dileep // Routledge. — 2019. https://books.google.com

7 Prideaux B. Creating visitor attractions in peripheral areas. In Managing visitor attractions: New directions / B. Prideaux // Routledge. - 2012. - P. 78-92. https://books.google.com

8 Bruinsma F. Tourism, culture and e-services: Evaluation of e-services packages / F. Bruinsma, K. Kourtit, P. Nijkamp // Research Memorandum. - 2011. - P. 16. https://dlib.info

9 www.aksu-jabagly.kz. Aksu — Zhabagly State Nature Reserve.

10 Schebal C. (2011). Evaluation of Tourist Destination Attractivness. https://scholar.google.ru

11 www.atameken.kz. Organization for the promotion of tourism will appear in Kazakhstan, 14 September 2016.

12 www.weforum.org/reports. Travel and Tourism Competitiveness Report 2016.

13 Kazakhstan National Committee. 2014 Kazakhstan National Committee for the UNESCO Program «Man and Biosphere»: Aksu-Zhabagly BIOSPHERE RESERVE. http://www.kazmab.kz

14 Yin H. The influence of big data and informatization on tourism industry / H. Yin, Y. Zhu // IEEE. - 2017. - P. 1-5. https://doi:10.1109/BESC.2017.8256393

15 www.unwto.org. PRODUCT DEVELOPMENT.

\title{
Иманалы Акбар, 3.Қ. Мырзалиева, А.Ж. Тәжекова, Б. Кенесбекқызы Ақсу-Жабағылы дүниежүзілік мұра нысаны маңындағы Жабағылы ауылындағы туристік өнімдердің даму жағдайы
}

\begin{abstract}
Туризм көптеген елдердегі негізгі табыс көздерінің бірі болып табылады, тіпті кейбір мемлекеттер қазіргі уақытта туризм индустриясына қатты тәуелді. Туристік кәсіпкерлік қызметтің негізгі мақсаты - халықаралық нарықта бәсекеге қабілетті туристік өнімдерді жасау. Осы мақсаттарға жету мемлекеттік реттеу жүйесін дамытуды, туризм индустриясын қолдауды және туристік өнімді жарнамалау әдістерін қолдануды талап етеді. Мақалада Ақсу-Жабағылы қорығының мысалында туризм индустриясын дамыту үшін ең қажетті туристік өнімдердің даму жағдайы ұсынылды және бағаланды. Зерттеу нәтижелері көрсеткендей, егер біз ең маңызды тұрар жай, көлік жолдары, туристік көрікті жерлер және электронды сервис дамуын қарастыратын болсақ, олардың даму деңгейі мен туристерге сапалы қызмет ұсыну жағдайы салыстырмалы түрде алдыңғы үшеуі бойынша жақсы деп айтуға болады. Зерттеу саласында аймағымыздағы электрондық қызмет көрсету (негізгі өлшемдер: телефон сигналы, интернет жылдамдығы, электронды билет және т.б.) сапасын талдау нәтижесінде, Қазақстанның шалғай ауылдық жерлерін жоғары сапалы интернетпен қамту мүмкіндігі барына қарамастан оның даму деңгейі төмен деп санадық.
\end{abstract}

Кілт сөздер: даму жағдайы, туристік өнімдер, туристер, Жабағылы ауылы, Ақсу-Жабағылы, табиғи қорық, әлемдік мұра, Қазақстан.

\author{
Иманалы Акбар, 3.К. Мырзалиева, А.Ж. Тажекова, Б. Кенесбеккызы
}

\section{Состояние развития туристической продукции в селе Джабаглы возле объекта всемирного наследия Аксу-Джабаглы}

Туризм является одним из основных источников дохода во многих странах, многие государства в настоящее время сильно зависят от индустрии туризма. Основная цель деятельности туристического бизнеса - создание конкурентоспособных туристических продуктов на международном рынке. Достижение этих целей требует развития системы государственного регулирования, поддержки индустрии туризма, использования методов продвижения туристских продуктов. В статье представлены итоги и оценено состояние развития наиболее необходимых туристических продуктов на примере АксуДжабаглинского заповедника. Наше исследование рассматривает состояние наиболее важных направлений, как проживание, транспорт, туристические достопримечательности и электронный сервис, что свидетельствует о том, что уровень их развития и условия предоставления качественных услуг туристам оптимальны по трем ранее указанным показателям. На основе анализа качества электронных услуг в области исследования (основные критерии: телефонный сигнал, скорость интернета, электронные билеты и т.д.) определен низкий уровень развития в данном регионе, тогда как в Казахстане имеется потенциал использования качественного интернет-покрытия в условиях его текущего развития.

Ключевые слова: состояние развития, туристические продукты, туристы, село Джабаглы, АксуДжабаглы, природный заповедник, всемирное наследие, Казахстан. 


\section{References}

1 Cracolici, M.F. \& Nijkamp, P. (2009). The attractiveness and competitiveness of tourist destinations: A study of Southern Italian regions. Tourism management, 30(3), 336-344. https://doi:10.1016/j.tourman.2008.07.006

2 Aliyeva, S., Chen, X., Yang, D., Samarkhanov, K., Mazbayev, O., \& Sekenuly, A. (2019). The Socioeconomic Impact of Tourism in East Kazakhstan Region: Assessment Approach. Sustainability, 11(17), 4805. https://doi:10.3390/su11174805

3 Tleubayeva, A. (2018). Rural tourism as one of the priority factors for sustainable development of rural territories in Kazakhstan. Journal of Environmental Management and Tourism (JEMT), 9(06(30), 1312-1326. http://dx.doi.org/10.14505/jemt.v9.6(30).21

4 Camilleri, M.A. (2019) Tourism planning and destination marketing. Emerald Publishing Bingley. https://doi.org/ 10.1108/978-1-78756-291-220181014

5 Yasarata, M., Altinay, L., Burns, P. \& Okumus, F. (2010). Politics and sustainable tourism development — Can they co-exist? Voices from North Cyprus. Tourism Management, 31(3), 345-356. https://doi:10.1016/j.tourman.2009.03.016

6 Dileep, M.R. (2019). Tourism, Transport and Travel Management. Routledge. https://books.google.com

7 Prideaux, B. (2012). Creating visitor attractions in peripheral areas. In Managing visitor attractions: New directions, Routledge, 78-92. https://books.google.com

8 Bruinsma, F., Kourtit, K. \& Nijkamp, P. (2009). Tourism, culture and e-services: Evaluation of e-services packages. Research Memorandum, 2011, 16. https:// dlib.info

9 www.aksu-jabagly.kz. Aksu-Zhabagly State Nature Reserve.

10 Schebal, C. 2011 Evaluation of Tourist Destination Attractiveness. https://scholar.google.ru

11 www.atameken.kz. Organization for the promotion of tourism will appear in Kazakhstan, 14 September 2016.

12 www.weforum.org/reports. Travel and Tourism Competitiveness Report 2016.

13 Kazakhstan National Committee. 2014 Kazakhstan National Committee for the UNESCO Programme «Man and Biosphere»: Aksu-Zhabagly BIOSPHERE RESERVE. http://www.kazmab.kz

14 Yin, H., \& Zhu, Y. The influence of big data and informatization on tourism industry. IEEE, 1-5. https://doi: 10.1109/BESC.2017.8256393

15 www.unwto.org. PRODUCT DEVELOPMENT. 